\title{
A QUALITATIVE STUDY ON MENTAL DISTRESS OF VIETNAMESE STUDENTS IN THE U.S.A. IN THE COVID-19 ERA
}

\author{
Ngoc Cindy Pham', Juehui Richard Shi2 \\ 1. CUNY - Brooklyn College, New York, USA \\ 2. Angelo State University, Texas, USA
}

Correspondence: dr.ngocphamcindy@gmail.com

\begin{abstract}
\section{OBJECTIVE}

This paper aims to examine how the COVID-19 pandemic affects the mental distress of the Vietnamese students in the USA. We explore different root causes of mental distress among international students who are away from their home country, their loved ones, and being isolated from school and community due to this outbreak.
\end{abstract}

\section{DESIGN}

In-depth interviews were conducted to probe the reasons for mental stress during the pandemic and the narrative textual analysis was subsequently performed to analyze the results. This research includes the interviews of 20 Vietnamese students in the USA during the COVID-19 era.

\section{RESULTS}

The textual analysis showed that the mental distress of these Vietnamese students were caused by limited access to oncampus facilities and activities, limited access to public services including grocery shopping, transportations, clinics, the possibility of being infected, isolated living condition due to the lockdown order, and inability to go back to the home country when wanted.

\section{CONCLUSIONS}

We found that both physical attributes (e.g., living condition, internet difficulty, overwhelmed healthcare system, restricted traveling, lack of personal interaction, limited access to public services) and psychological factors (e.g., anxiety of unfamiliar teaching modality, fear of viral infection, uncertain career aspects, cultural barrier and prejudice) directly led to the mental distress of these students. Moreover, other factors such as turbulent future job markets and potential racism toward Asians in relation with "Chinese virus" may cause the mental distress of these students.

\section{KEYWORDS}

COVID-19; Vietnamese students; Mental distress; Narrative textual analysis; Racism

\section{INTRODUCTION}

Mental distress is a worldwide crisis. Around the globe, about 800,000 people died from suicide in 2016. [1] According to the National Institute of Mental Health, depression affects approximately $6.7 \%$ of all US adults but many are reluctant to seek professional help for depression. $[2,3]$ The mental distress persists not only in developed countries such as the United States, but also in developing countries such as Vietnam. Anxiety disorder such as panic and specific phobia, and mood disorder such as depression are all commonly observed mental illnesses. Mental distress becomes an even more important concern for the society given the current COVID-19 situation. [4, 5, 6] Students are facing new challenges including adapting to new lifestyle of working from home, social-distancing, home-schooling of children, worrying of losing jobs, and 
fear of the wide-spread virus. [7, 8, 9] These traumas caused by COVID-19 significantly and negatively affect the amount of optimism, self-esteem, and social support which then lead to increased levels of mental distress among college students. [10] Several news articles have recorded the mental distress caused by COVID-19 among Vietnamese students in the USA. [7, 8, 9] Although scholarly studies of students' mental distress have been undertaken, $[10,11,12]$ there exists a research gap for the mental distress of Vietnamese students in the USA during the COVID-19 pandemic.

The number of international students in the USA is $1,095,299$ in the 2018-2019 academic year, with 31,613 Vietnamese students. $[13,14]$ Many international students are coming to the USA for education, safety, security, and the possibility of future career in the US after graduation. However, during the COVID-19 outbreak, the US has the highest number of COVID-19 cases across the world. This poses serious challenges to the education and career prospects of prospective international students. Research has shown that college students are more prone to varying mental disorders. $[10,11,12$, 15] We think that the COVID-19 environment may accelerate the current mental disorders or serve as a catalyst for potential mental distress down the road, especially among the young population. Therefore, this paper addresses an urgent research question below:

What are the factors that could lead to mental distress of Vietnamese students in the US during the COVID-19 epidemic?

The contributions of this study are two-fold. Firstly, the indepth interviews conducted during the time period of the COVID-19 outbreak are unique, revealing interesting insights regarding the mental distress of those who are affected by the COVID-19 crisis. Secondly, findings of this research generate important practical implications for the healthcare services and establishments, particularly among the international student population.

This paper is organized as follows. In Section 2, we briefly review the mental distress literature among college students and discuss the importance of this study. The research methodology is described in Section 3. Sections 4 , 5 , and 6 are dedicated to interview findings, discussion of the results, and managerial implications. Lastly, we conclude this study and explore possible avenues for future research in Section 7.

\section{LITERATURE BACKGROUND OF MENTAL DISTRESS}

Research in mental distress is highly relevant and important for college-aged students since mental distress has been a common health problem among this young group. [12] Just recently, several studies found that college students are at an increased risk of having mental distress. $[12,15,16,18$, 19] In addition, it has been shown that college age is a vulnerable stage where many mental health problems, such as anxiety disorders and mood disorders, first surface. [17] A survey on U.S. college students indicated that $30 \%$ $50 \%$ students were diagnosed or treated for at least one psychiatric disorder in the last 12 months. [16] Another crosssectional study on the mental health of UK veterinary undergraduates found that $54 \%$ of the respondents had experienced mental illness. [18] In a mental health study of the Australian university students, nearly one-fifth reported the mental health problems, and an additional $67.4 \%$ of the students reported the subsyndromal symptoms. [19] More than one third of the university students in Ethiopia have suffered mental distress. [12] Without doubt, university students are the high-risk population for having mental health problems and the need for early intervention to prevent severe mental illness was therefore suggested. [12, 18, 19]

Daily stress was also found to increase depression and anxiety as well as negatively impact the long-term wellbeing of the university students. [20] At the time of COVID-19 outbreak, because of the severe disruption of daily routine and normal life along with other uncertainties, young college students are vulnerable to mental health issues. [21] Extending the extant literature, we examine the mental distress of the Vietnamese students staying and living in the USA during the COVID-19 pandemic.

\section{RESEARCH METHODOLOGY}

This study utilizes the in-depth interview methodology to understand the mental distress of Vietnamese students in New York City (NYC), New York, USA during the COVID-19 outbreak. The in-depth interviews help to derive individual's opinions, emotions, and feelings, providing us with unique and interesting insights into their daily life. [22, 23] The causes of the mental distress among these students are explored and discovered in the interview process. 


\subsection{INTERVIEW PROCEDURES}

20 Vietnamese students from six different colleges in the NYC area were recruited via Facebook page of "Vietnamese students in NYC". The six universities comprise CUNY - Brooklyn College, CUNY - Baruch College, New York University (NYU), Berkeley College - NYC, Long Island University (LIU), and Kingsborough Community College (KCC).

Each interview lasted around 30-45 minutes via Zoom in March-April 2020. These participants preferred being interviewed in Vietnamese only. None of the interviews was conducted in person since social distance order was strictly required in NYC. Participants could choose to be interviewed in group of 3 to 5 or individually.

We recorded video interviews with participants' consent, preserving anonymity. Triangulation was used to ensure consistency of the interpretations of the interview transcripts with two authors' agreement on the same meaning after checking the recorded texts. Among these 20 students, there are 8 males and 12 females. These students (aged 19-33) have been in the USA from 7 years to less than 4 months. Demographics of these students are provided in Table Al.

\subsection{NARRATIVE TEXTUAL ANALYSIS}

The audio and video recordings of the interviews were translated from Vietnamese to English and transcribed by two researchers who are fluent in both Vietnamese and English. We chose the narrative textual analysis because it provided us with an in-depth understanding of how participants viewed the world around them. [22, 23, 24] We first listened and observed the recorded interviews to make sense of the participants' responses and then interpreted what the participants meant. Finally, the authors must agree upon the interpretations of the interview transcripts. Then the narrative textual analysis was conducted by these two researchers to examine the participants' concerns about COVID-19 impact on their lives.

We started asking participants "what" changes COVID-19 had made to their lives and "how" they felt about the changes. By asking "what" questions, we try to learn about the different sources of mental distress these students were experiencing. "How" question tries to capture how participants were dealing with the changes caused by COVID-19. At the same time, we also cross-checked the interview transcripts, finding similarities and comparing differences in the participants' responses.
The follow up questions, for example, "would you please elaborate what you meant by racist look or racism behaviors of the locals toward you being an Asian?" or "tell me more about your experience of remote learning" complemented the interview.

\section{INTERVIEW FINDINGS}

This research explores the root causes of mental distress among Vietnamese students in NYC. In the following space, we identify eight such major causes along with detailed transcripts from the interview recordings.

\subsection{CAUSE 1: UNSAFE LIVING CONDITION}

Yen Trinh, Master of Computer Science, has just moved from Massachusetts to a programming internship for a Wall Street financial company since January 2020. Because of the small salary on her OPT internship, she must live with six other girls from different countries in three cramped bedrooms in Manhattan.

'One of my roommates has been infected with COVID-19 since last week. I am and others are very scared...Eight of us here are living in a threebedroom apartment...l can't move out. With my internship salary, I can't rent my own apartment in Manhattan.' (Yen Trinh)

She cannot move out of Manhattan for a more affordable place because she needs to live close to her workplace.

'I need to be near my workplace... Morning times in Manhattan are very crowded... A lot of traffic jams... Subways are always packed in the a.m. I'm afraid of being late for work'.

Nhi, is in a lawsuit against her landlord.

'I heard that one person sharing the apartment here is infected. I tried to move out A.S.A.P. but the owner does not let me break the contract... I deposited 2,000 USD, so if I moved out now, it would be lost...My one-year contract here is until this December 31 st...I am looking for a real estate lawyer to fight for my right and safety...' (Nhi)

Anh, is in an uncertain situation in his shared apartment.

'I share the apartment with two others. I don't know them. I just rent the room via a room-for-share 
website for students...l am praying that the other two are taking care of themselves because if they get sick, I may catch the virus too...I am wearing mask to go the common areas within the apartment such as the kitchen and restroom...l have stayed in my room all of the times'. (Anh)

\subsection{CAUSE 2: INTERRUPTIONS OF SCHOOL}

Nguyen, from Hanoi, is an international student of Brooklyn University. He has been in New York for 4 years. He says he loves New York because it is an energetic city with many opportunities.

'I miss my friends from the Badminton Club. I have not seen them since March 20 (the day Brooklyn College was shut down due to the pandemic).'

'I miss my practicing badminton. It was my daily ritual for the past two years here.'

'I usually stay in the library to study with friends after my classes. Now, I cannot even visit the library for printing services.'

'I enjoy group study.'

Khanh, just came to the USA in January 2020 to join the MBA program at LIU. He is sharing the apartment with seven other students also from Vietnam.

"I love going to campus. To me, it is a real schooling experience.'

'I study via Zoom everyday...Internet is disrupted sometimes... Remote-learning is not the same with going to school...'

'I took pictures of myself and then shared on Facebook so that my family and friends in Vietnam can see my international student life in the States...Lately, I seldom take pictures because they are same things every day...Nothing is new...I am basically at home the whole day...'

'My roommates are also taking online classes. We sit in the living room and study together.'
Quynh, Khanh's roommate, is an undergrad student at LIU. She is studying Accounting. This Spring is her second semester in the US.

She comments,

'This is not the study abroad life I imagined. I am home 24/7 while being in the most exciting city in the world.'

"I loved going out to shopping malls and parks to mingle with local people. I learned English from talking to them.'

'Before this mess, we often took a train to the centre of the City...Sometimes I went with the roommates. Sometimes I went with my Chinese classmates. I saw many splendid buildings...I learned a lot about America.'

Trang, MBA student at NYU. She is living with her husband in an apartment near Central Park. Her husband, Thang, is a Master student at Baruch College. They have been in NYC since 2018.

Trang said

'More homework and assignments in remote learning classes than in face-to face classes.'

'Bored at online classes.'

'I prefer going to campus and have real lectures.'.

Thang added,

'Going to school means attending on-campus lectures. I paid for the lectures, not for theses online sessions...The experience is not the same...'

Minh, complained,

'Some professors simply converted my face-toface classes to the $100 \%$ online format...I hardly hear from them. They just disappeared...'

Kim, added,

'Many professors posted PowerPoint slides and assignments on Blackboard. There is no online lecture since March. It has been five weeks 
now...My friends from other classes even had to contact the Chairperson of the Department and the Dean for help.'

\subsection{CAUSE 3: INTERRUPTIONS OF WORK}

Minh Hieu, studying for a master's degree, has been in New York for 1.5 years. Hieu works part-time in a Chinese restaurant in the Brooklyn area. The restaurant was closed because of the NYC 's social distancing order, so she lost her job. Previously, with the tips received daily, she could afford the living expenses. Hieu now asks for some support from her family in Vietnam while also spending her savings.

'I have no income since the lockdown order in New York. I am using up my saving for the tuition of the Fall semester. I am worried that I may spend all of the saving for the Fall semester tuition and cannot register for classes.' (Hieu)

"I am worried if the shutdown lasts longer than the summer, I may have to go back to Vietnam...I may have no saving left for the Fall semester.' (Hieu)

In the similar situation are Lan (KCC) and My (Brooklyn College) who moved to the NYC from Vietnam in 2018. Lan was working at a nail salon while My was working at a hair salon in the Brooklyn - Chinatown area before the shutdown. They have been unemployed since then while ineligible for disaster aids from the US government.

'I was paid cash when working... I do not have the Social Security Number...l do not apply for unemployment help...' (Lan)

My added,

'I heard that the aids such as Emergency Disaster Relief are only for Americans. I am an international student here...I have received no help from the government...All my friends are in the same situation.'

Vy, from Saigon, graduated from Baruch University in 2018, working for a financial company in Jersey City. Vy now works from home. Although her job has not greatly affected by remote working, Vy also encountered some difficulties such as bad Internet connection.
'Internet at home is not strong or stable. I just have to call the IT staff from my company to help fix the Internet problems at my home yesterday...I think there are too many people working at home and using internet...'

'I miss going to the office'

'More work for me while working at home than when I was going to the office.'

'You cannot take a break when you are working at home. They (customers and bosses) expect you to be at the computer the whole time.'

\subsection{CAUSE 4: GOT SICK AND HAVING LIMITED ACCESS TO HEALTHCARE SERVICES}

Phuong, from Hanoi, last year student at Berkley College, was infected with COVID-19. She just recovered recently. She recounted the terrible time with all the symptoms of COVID-19.

When she found out she was infected, she called all the hospitals in NYC to get tested but no one answered the phone. She could not make an appointment in person because all of the COVID-19 testing centres and hospitals were overloaded.

'Unless you are about to die, you cannot get to the hospitals for testing or treatment.' (Phuong)

'One of my friends called the hotline for days when she got the fever, but no one answered. She recovered by herself after the sick days...It was an extremely horrible experience for her and her family in Vietnam.' (Trang)

'I heard from several students in my Facebook group that it is impossible to ask for COVID-19 test lately.' (Vy)

Apparently, health facilities here have not yet been prepared to combat this pandemic.

Phuong had to cure herself with common cold medicine according to the doctors' remote instructions.

'I have to take care of myself. I have learned to cure for myself. Before this pandemic, I was so 
confident that I was living in the most developed country in the world with the best healthcare system...It seemed not...l am scared now...' (Phuong)

Vy and Giang are worried if they get infected, who will pay hospital fees - they themselves or their student insurances, and which kind of student insurance will cover the treatment of this new disease.

'We just try to protect ourselves by staying home and pray that we are not infected. We do not trust the healthcare system here anymore after the pandemic experience...They did not or could not help patients.' (Trang and Thang)

\subsection{CAUSE 5: CANNOT GO BACK TO THE HOME COUNTRY}

When we asked why these students chose to stay in the US, they said they were worried about the high risk of getting the virus on the planes and/or at the airport.

'I read on news that many people got infected on the plans' (Trang)

'I am fine so far here (at home). I just lock the door and stay home. I cannot control whom I may interact with at the airport.' (Vy)

'My family told me to stay right there...Don't try to go anywhere... It is safer to stay at my apartment now than on the flight.' (Khanh)

Besides, traveling back to Vietnam from the US is not as easy as before.

'There is a long list of students want to fly back to Vietnam at this time. It is not easy to go back now as compared to normal times' (Vy)

'It is not like you buy the ticket and you can fly back tomorrow or anytime soon... There are not many flights from the US to Vietnam. The Vietnamese government limits the international flights from and to Vietnam.' (Trang)

'We have to register with the Vietnamese embassy in the USA to buy flight tickets to Vietnam... There is a quota for the tickets.' (Phuong)
'Most of our friends flew back to Vietnam in February when the pandemic news broke down in the US... We have some friends decided to fly out last week (early March) which is already late... Those flights were the last chances for us...The only thing we can do now is to stay in the dorm room, avoid going out to public places, and try to take care of ourselves...' (brothers from Hanoi, Trung, and Lam, both NYU students)

Also, some students showed concerns about the mandatory 14-day quarantine once they arrive in Vietnam. Vy and Trang are worried that the 14 days of quarantine could disrupt their ongoing urgent work...

'I am taking online classes now. I need the stable internet to watch remote lectures and complete the weekly assignments...' (Trang)

'I need to access the internet every day for work.' (Vy)

'My Mom told me that everyone coming back from overseas must stay in the quarantine centres for 14 days. It is mandatory. What if the internet is bad or there is no internet, I may not be able to finish this semester.' (Khanh)

Some students raised the concern that if they leave now, they may not be able to get back to the US after the pandemic. Thus, they choose to stay in NYC.

'I am on Fl-visa (international student visa status). I am afraid they (US embassy) will not renew my visa to get back here after the pandemic.' (Nhi)

'I just arrived NYC 3 months ago. I don't want to go back to Vietnam now and raise the red flag to the US Immigration Officers... I need to finish the first semester of my program ...I am planning to wait until the summer to go back...' (Khanh)

'I am on OPT (working permission after graduation) now. If I go back, it may be difficult to reapply for the visa to come since I do not have any reason.' (Vy)

'I am graduating next year. I am looking for an internship so that I can apply for my OPT. If I fly out 
of the USA now, I think that the USA embassy in Vietnam will not grant me the entry visa after this pandemic.' (Phuong, Berkeley College).

These students show concern that when the pandemic is over and when they can travel to see their loved ones again.

'I miss my Mom. I have not seen her since last year. We have been on the phone every day, but it is not the same you know... The sad thing is we don't know when we can see each other...' (Phuong)

'I really hope I can travel again in the summer. But it really depends on the pandemic situation...' (Khanh)

\subsection{CAUSE 6: ISOLATION AT HOME, UNABLE TO ACCESS TO PUBLIC FACILITY (E.G. GROCERIES AND LAUNDRY ROOM)}

Isolation is an issue that these international students are facing in COVID-19. Phuong did not go out since March 18. All activities are around the apartment she rents with a friend from the same country.

'I order all groceries delivered to my door...I did not even talk to my roommate... l cook and then text her to get the food in the kitchen when she is hungry. We do not eat together like before. I close my room door and she closes her door...This is safe...We text each other to communicate when we need.' (Phuong)

'We have not gone out since March... We have not done laundry in 4 weeks.' (Trang and Thang)

'The only two times I had to go out were to do laundry...My girlfriend is staying with me since quarantine, so I am not too lonely. We are just cooking and eating different dishes...' (Anh)

Khanh and five other friends can only narrow their life around the vacant lot in front of their building.

'Sometimes I really need to just get out of the apartment...I wear a mask and walk around the down stairs area of my apartment complex...I was walking alone and try to avoid all possible contacts with others...They avoid me too...' (Khanh)

\subsection{CAUSE 7: UNSTABLE FUTURE ON CAREER AFTER GRADUATION AND RACISM}

A major concern of international students is whether they should stick to their original plans of staying back in the USA after graduation or they should return to their home country.

Vy, was hoping for a job with a visa sponsorship, said,

'I used to believe very much in my chosen career because I am now working full time for a big financial company. But now we are unsure of the future of the New York's financial industry.' (Vy)

'I was unable to find an internship. I was applying in January this year, right before the shutdown. But I have not heard anything from the companies that I applied...I am worried since the OPT application deadline is approaching...' (Phuong)

These students as well agree on the racism wave toward Asians since the pandemic outbreak due to the terms of 'Chinese virus' or 'Wuhan virus' which associate the Asian ethnicity with this deadly pandemic.

'Back in February, when I entered a subway cart, two women covered their noses with their shirt collars immediately...They think all Asians carry COVID-19.' (Nam, Baruch College)

'When I was running in the park near my house, some men and women tried to approach me and yell racial slurs to me... It was in March...' (Thanh, College)

'As early as February, sometimes when I walked to the nearby grocery stores or convenient stores, the local people attempted to stay away from where I stood as far as possible... They even gave me strange look...' (Thu, KCC)

'They screamed at me, cursed me, and called me 'Viru' one night when I walked home from the subway station.' (Anh)

'A cashier of the grocery store near my home specifically requested me and my husband to wear masks and stay 6 feet away from him when we at the check-out counter. He did not ask the customers in front of us to do so...' (Trang) 


\subsection{CAUSE 8: CULTURAL FACTORS}

Vietnamese people, who appreciate the close-knit neighborhood and community, are inclined to keep close relationships with their neighbors. The neighbors are often visiting and chatting with each other, sharing ideas, and talking about daily life. They believe that these people are whom they can count on in the time of need. The proverbs 'Ban anh em xa mua lang gieng gan' (i.e., your siblings who are living far away cannot help you as much as the nextdoor neighbor can) or 'Hang xom toi lua tat den co nhau' (i.e., You have your neighbor when it is dark) reflect the strong believes of Vietnamese people's reliance on their close community.

Thus, living isolated in their own shelters is stressful for these Vietnamese students.

'I have not seen any of my neighbors since the shutdown...' (Thanh)

'Everyone is trying to avoid others...People walk fast on the street... They keep their faces down...They avoid any form of communications at all cost...' (Nam)

'I have been on the phone with my parents 24/7 since March. I am living in NYC but now I feel like I am living in a lonely planet...The streets are too quiet...I hardly can see anyone on the street from my windows here.' (Phuong)

\section{DISCUSSION}

Based on the detailed transcripts of the in-depth interviews conducted in Section 4, we have identified eight major causes for the mental distress among the Vietnamese students during the COVID-19 outbreak, concerns ranging from unsafe living condition, interruptions of school and work, unable to visit the home country, limited access to healthcare services and facilities, high healthcare cost for the virus, feeling isolated, uncertain career prospects, to cultural differences and prejudice.

Firstly, limited choice of an affordable and comfortable shelter in NYC makes the living situation quite challenging and dangerous for one of the most vulnerable populations in the USA-international students. Research showed that rental housing unaffordability is one of the significant causes for mental distress among immigrants. [25] NYC has one of the highest rental rates in the world. [26] These international students, who mostly live on the financial support from the family back home, are struggling with the high rental cost in the City.

Secondly, unconventional learning environment such as online or remote is unfamiliar to the traditional students, disrupting the conventional studying habits thus creating anxiety and uncomfortableness among the students. Previous studies indicated that college and university students are anxious about dormitory evacuation and cancellation of anticipated events such as exchange studies and graduation ceremonies. [27] Remote learning also diminishes personal interaction and communication, reducing the hands-on opportunity for the international students to practice English and experience the Western culture. $[8,9]$

Thirdly, work is disrupted due to technical difficulties (e.g., high internet usage low bandwidth) and longer working hours per day and per week. A recent article showed that being forced to stay home, working from home, reducing social interaction, and working many hours under stressful circumstances have a major negative impact on worker's daily functioning and night-time sleep, which subsequently lead to the rising in stress level. [28]

Fourthly, the students are distressed because they are in fear of the restricted travel to their home country during the pandemic while not knowing how long this travel restriction is going to last. Homesickness is one of the challenges that international students may encounter when they leave home. [29] And the self-quarantine and shut-down orders in COVID-19 in NYC are worsening the homesickness. Since the pandemic, Vietnamese students in NYC have been staying home in a foreign country for an uncertain amount of time, which lead to potential trouble in social interactions and sociocultural adjustment. [30]

Fifthly, due to the overwhelmed healthcare system in NYC, some students are unable to get timely diagnosis and treatment of the virus. Numerous interviews with doctors, hospital administrators, and health officials revealed a confusing and often troublesome virus testing system in New York City that left many people who suspected that they had been exposed to the coronavirus deeply frustrated. [31] Until the end of April 2020, NYC still was not able to provide COVID-19 testing services in many hot spots in the city, especially in communities of colour. [32] This suggests that during the peak of this pandemic there had 
been many areas in the city struggling with providing COVID-19 testing and treatments for the residents. In addition, these students show concerns about the possible high cost of treatment and inadequate health insurance coverage. As of the end of March, it was unclear whether student insurance is adequately and timely equipped for this pandemic, thus causing lots of students to be worried. $[8,9]$

Sixthly, depression among the students is an unavoidable side effect created by the isolation for human contact necessary and essential during the COVID-19 epidemic. These traumas caused by COVID-19 significantly and negatively affect the amount of optimism, self-esteem, and social support, leading to increased levels of mental distress among college students. [10]

Seventhly, the students are worried about the future career prospects and their so-called "American dream". [7, 8, 9] Study of Han and Appelbaum [33] revealed that $77 \%$ of the STEM international PhD graduates by 2020 in the United States want to remain in the U.S.A. Anti-Asian phenomenon in America during this pandemic is also a critical issue and a big concern for these Vietnamese students. There are many reports on the racism against the Asian community in America. [34, 35].

Eighthly and lastly, the collectivism and uncertainty avoidance of the Vietnamese students intensify their worrisome and isolated feelings because of the lack of human interaction and uncertain virus situation. The uncertainty avoidance dimension of culture captures the 'extent to which a society, organization, or group relies on social norms, rules, and procedures to alleviate the unpredictability of future events.' [36] People in high uncertainty avoidance cultures focus on stability and security are less likely to take risks, whereas those in low uncertainty avoidance cultures tend to demonstrate more tolerance toward unstructured and ambiguous situations are more likely to take risks. [37] Members in uncertainty avoidance societies appreciate confirmation and prefer predictability in their lives. [38, 39] Vietnamese college students' high tendency to avoid uncertainty is likely to influence their behaviors during the COVID-19 pandemic. When the COVID-19 situation is unclear, these Vietnamese students (with higher uncertainty avoidance) turn out to be more distressed and worried compared to their American counterparts (with lower uncertainty avoidance).
This cultural factor may compound the mental distress among these students. Currently, many Vietnamese students in New York are facing all kinds of worries: losing their jobs if they are working in a restaurant, milk tea shop, beauty facilities, nail salon; or uncertain future if they are practicing or having an internship at American corporations. The devastating consequences of the virus is substantial not only physically and financially but also mentally and psychologically as we see in Section 4.

\section{MANAGERIAL IMPLICATIONS}

The interviews we conducted in this study reveal the eight root causes for potential mental illness (i.e., depression, PTSD_Post Traumatic Stress Disorder) pre- and post-COVID19 outbreak in NYC. They provide mental health professionals with important insights to diagnose and treat the patients affected by the COVID-19. We believe that the densely populated city area and usual busy city life pose great challenges for those who are used to the bustle and hustle of the big city during this pandemic. The compounded stress from both the city and the virus could take a tremendous negative toll on the city people. We suggest that the mental health professionals implement special tailored diagnosis procedures and treatments for those staying in the city during the pandemic. The treatment should focus on finding the root cause of the mental health issue rather than masking the symptom. The treatment should also be distinguished depending on demographics, occupation, cultural background, previous mental history, family relationship, financial situation, employment status, and education.

For the international students like those from Vietnam in NYC, independent living away from home, the difficulties in daily life such as shopping and waiting in line, grocery shortage, online ordering service for an extra charge, washing day-to-day clothes to avoid infection, being hindered by remote learning, uncertainty about school opening and future career aspects, and cultural barrier and prejudice intensify their anxiety of arriving, studying, and staying in the "big apple." In addition to the assistance from mental health professionals, the schools hosting these students should find ways to alleviate the negative effect of COVID-19 by creating a family feeling culture in the school, providing necessary free mental consultation to the students and keeping track of their mental status, and keeping students informed of the changes in job market and daily life. 
Moreover, in addition to the interview transcripts we collected in Section 4, there are also very interesting stories of Vietnamese students in New York that many students hesitate to share. Consistent with previous studies on mental health among students, $[10,11,12,18,19,20]$ this research finds that college-student group is very sensitive with dramatic life changing events and more easily to be distressed. This study contributes to the extant mental health literature by utilizing a unique narrative textual analysis of the personal interviews conducted among the Vietnamese students living in NYC during the COVID-19 epidemic.

Lastly, similar studies among other groups of international students in the US such as Chinese, S. Korean, Thais, or even to European groups and African groups are necessary. The international students in the USA are already stressed due to being away from their home country and the loved one, now facing life changing occurrences caused by COVID19. The American healthcare system may need to find a way to approach the international students in order to help them with the mental distress caused by COVID-19. Vietnamese government as well as these students' American universities also thinks of solutions to provide professional mental health services for their students in this critical time. In Asian culture, people enjoy the city activities (e.g., night life, dining out, group gathering). Thus, the shutdown in COVID-19 is a big cultural shock for these students.

\section{CONCLUSIONS}

This study provides a unique set of empirical evidence for understanding the root causes of mental distress among the Vietnamese students staying and living in US during the COVID-19 pandemic. Based on the in-depth interviews, we have identified eight sources for mental distress. We find that the mental distress is caused by both physical attributes (e.g., living condition, internet difficulty, overwhelmed healthcare system, restricted traveling, lack of personal interaction, limited access to public services) and psychological factors (e.g., anxiety of unfamiliar teaching modality, fear of infection, uncertain career aspects, cultural barrier and prejudice).

Although the sample is interesting and relevant to the aim of this study, its size is limited due to the nature of the interview method we implemented and the sample group who were present and willing to provide detailed answers, especially during the COVID-19 era. Nonetheless, the small sample size of this study may make it difficult to generalize the findings and replicate the results. Therefore, it is imperative for researchers to use other methodology and a larger sample size to compare with our findings. For example, regression analysis, such as basic Ordinary Least Squares (OLS), more advanced Simultaneous Equations Systems (SES) [40] and Seemingly Unrelated Regressions (SUR), [41] can be used to find the causality and the significance of the factors that influence mental distress. Factor analysis is also useful for developing new measures for the eight sources of students' mental distress which we have identified in this study or for discovering additional sources. In addition, we suggest collecting a panel dataset to explore the long-term effect of COVID-19 on students' mental condition as well as periodically checking how the mental health status of these students change after the pandemic is fully over. The panel dataset, in our opinion, is more dynamic and a step closer to the real-world situation. Econometrics time-series models such as advanced Vector ARIMA or a simple version Vector AR (VAR) can be undertaken to study the cause-and-effect relationship between the students' mental distress and the impact of COVID-19 both short-term and long-term. Moreover, future studies can examine the mental distress on different groups of students from different ethnicities and backgrounds for comparison.

\section{References}

1. World Health Organization. World health statistics 2018: Monitoring health for the SDGs, sustainable development goals. 2018 [cited 2020 06/17]; Available from:

http://apps.who.int/iris/bitstream/handle/10665/27259 6/9789241565585-eng.pdf? $\cup a=1$.

2. National Institute of Mental Health. Major depression. 2017-11 [cited 2020 06/13]; Available from: https://www.nimh.nih.gov/health/statistics/majordepression.shtml

3. Van Zoonen, K., Kleiboer, A., Beekman, A., Smit, J., Boerema, A., \& Cuijpers, P. (2015). Reasons and determinants of help-seeking in people with a subclinical depression. Journal of Affective Disorders, $173,105-112$.

4. Phạm, N. Người Việt ở New York kể chuyện những đám tang buồn giữa tâm dịch COVID-19. 2020-05-06 [cited 2020 06/17]; Available from: https://thanhnien.vn/doi- 
song/nguoi-viet-o-new-york-ke-chuyen-nhung-damtang-buon-giva-tam-dich-COVID-19-1219204.html.

5. Phạm, N. Việt kiều Mỹ bình tâm trong đại dịch COVID19, mong trở về thăm Việt Nam. 2020-04-28 [cited 2020 06/17]; Available from: https://thanhnien.vn/doisong/viet-kieu-my-binh-tam-trong-dai-dich-COVID-19mong-tro-ve-tham-viet-nam-1216531.html.

6. Phạm, N. Phận đời nghệ sĩ hát rong ở New York thời đại dịch. 2020-04-14 [cited 2020 06/17]; Available from: https://thanhnien.vn/van-hoa/phan-doi-nghe-si-hatrong-o-new-york-thoi-dai-dich-1210553.html.

7. Phạm, N. New York giữa tâm dịch COVID-19: Cái nhìn của nữ PGS Việt đang dạy ở đây. 2020-04-04 [cited 2020 06/17]; Available from: https://thanhnien.vn/doisong/new-york-giva-tam-dich-COVID-19-cai-nhincua-nu-pgs-viet-dang-day-o-day-1205660.html.

8. Phạm, N. Diễn đàn Bình tĩnh trước dịch bệnh: Ngày dài của du học sinh Việt ở New York. 2020 2020-04-18 [cited 2020 06/17]; Available from: https://thanhnien.vn/doisong/dien-dan-binh-tinh-truoc-dich-benh-ngay-daicua-du-hoc-sinh-viet-o-new-york-1212285.html

9. Phạm, N. Du học sinh Việt giữa tâm dịch COVID-19 ở New York: Thay đổi 'giấc mơ Mỹ'. 2020 2020-04-21 [cited 2020 06/18]; Available from: https://thanhnien.vn/doisong/du-hoc-sinh-viet-giua-tam-dich-COVID-19-onew-york-thay-doi-giac-mo-my-1213561.html.

10. Knowlden, A. P., Hackman, C. L., \& Sharma, M. (2016). Lifestyle and mental health correlates of psychological distress in college students. Health Education Journal, 75(3), 370-382.

11. Pham, N., Li, Y., Hossain, T., Schapsis, C., Pham, H., \& Minor, M. (forthcoming). Understanding Mental Health Services and Help-Seeking Behaviors Among College Students in Vietnam. Asia-Pacific Journal of Health Management.

12. Dachew, B. A., Bifftu, B. B., Tiruneh, B. T., Anlay, D. Z., \& Wassie, M. A. (2019). Prevalence of mental distress and associated factors among university students in Ethiopia: a meta-analysis. Journal of Mental Health, 18.

13. Morris, C. Number of international students in the United States reaches new high of 1.09 million. 2018 2018-1113 [cited 2020 06/18]; Available from: https://www.iie.org/WhyIIE/Announcements/2018/11/2018-11-13-Number-ofInternational-Students-Reaches-New-High

14. Ashwill, M.A. Vietnamese student enrolment in the US holds steady. 2020 2020-02-08 [cited 2020 06/18]; Available from: https://www.universityworldnews.com/post.php?story $=20200205124654543$

15. Lee, J. (2020). Mental health effects of school closures during COVID-19. The Lancet Child \& Adolescent Health, 4(6), 421.

16. American College Health Association. (2018). American College Health Association National College Health Assessment II: Reference group executive summary, fall 2017. Hanover, MD: Author. Retrieved on February 14, 2020 from https://www.acha.org/documents/ncha/NCHA-

II_FALL_2017_ REFERENCE_GROUP_EXECUTIVE_SUMMARY.pdf

17. Kessler, R. C., Berglund, P., Demler, O., Jin, R., Merikangas, K. R., \& Walters, E. E. (2005). Lifetime prevalence and age-of-onset distributions of DSM-IV disorders in the national comorbidity survey replication. Archives of General Psychiatry, 62, 593- 602.

18. Cardwell, J. M., Lewis, E. G., Smith, K. C., Holt, E. R., Baillie, S., Allister, R., \& Adams, V. J. (2013). A crosssectional study of mental health in UK veterinary undergraduates. Veterinary Record, 173(11), 266-266

19. Stallman, H. M. (2010). Psychological distress in university students: A comparison with general population data. Australian Psychologist, 45(4), 249257.

20. Schönfeld, P., Brailovskaia, J., Zhang, X.C., \& Margraf, J. (2019). Self-efficacy as a mechanism linking daily stress to mental health in students: A three-wave crosslagged study. Psychological Reports: Mental \& Physical Health, 122(6), 2074-2095.

21. Zhai, Y., \& Du, X. (2020). Addressing collegiate mental health amid COVID-19 pandemic. Psychiatry Research, 288, 113003

22. Pham, N. C., Pham, H. H., Hossain, T., \& Li, Y. (2020). Servicescapes in healthcare: A qualitative study on the elderly's perception of an aged care facility. AsiaPacific Journal of Health Management, 15(1), 26-34.

23. Hossain, T., Pham, H. H., Pham, N., Hoang, M., \& Nguyen, S. (2019). A qualitative study of consumers' perceptions of the Affordable Care Act. Theoretical Economics Letters, 9(05), 1569.

24. Riessman, C. K. (1993). Narrative analysis (Vol. 30). Sage.

25. Li, T., Liu, R., \& Qi, W. (2019). Regional Heterogeneity of Migrant Rent Affordability Stress in Urban China: A Comparison between Skilled and Unskilled Migrants at Prefecture Level and Above. Sustainability, 11(21), 5920. 
26. Velsey, K. Why Rents Haven't Dropped in New York City. 2020 2020-06-18 [cited 2020 07/01]; Available from:https://www.nytimes.com/2020/06/18/realestate /why-rents-havent-dropped-in-new-york-city.html.

27. Lee, J. (2020). Mental health effects of school closures during COVID-19. The Lancet Child \& Adolescent Health, 4(6), 421.

28. Altena, E., Baglioni, C., Espie, C. A., Ellis, J., Gavriloff, D., Holzinger, B., ... \& Riemann, D. (2020). Dealing with sleep problems during home confinement due to the COVID-19 outbreak: Practical recommendations from a task force of the European CBT-I Academy. Journal of Sleep Research, e13052.

29. Billedo, C. J., Kerkhof, P., \& Finkenaver, C. (2020). More facebook, less homesick? Investigating the short-term and long-term reciprocal relations of interactions, homesickness, and adjustment among international students. International Journal of Intercultural Relations, 75, 118-131.

30. Mesidor, J. K., \& Sly, K. F. (2016). Factors that contribute to the adjustment of international students. Journal of International Students, 6(1), 262-282.

31. Goldstein, J., Ferre-Sadurni, L. \& Randle, A. Coronavirus in N.Y.: Desperate for a Test, They Couldn't Get One 2020 2020-03-11 [cited 2020 07/04]; Available from: https://www.nytimes.com/2020/03/11/nyregion/coron avirus-testing-newyork.html.

32. CBSNewYork. 2020 2020-04-17 [cited 2020 07/04]; Available from: https://newyork.cbslocal.com/2020/04/17/coronavirus -nyc-expanding-testing-for-hot-spot-communities-ofcolor/.

33. Han, X., \& Appelbaum, R. P. (2016). Will They Stay or Will They Go?: International STEM Students Are up for Grabs. Ewing Marion Kauffman Foundation.

34. ADL Fight Hate For Good. Reports of Anti-Asian Assaults, Harassment and Hate Crimes Rise as Coronavirus Spreads. 2020 2020-06-18 [cited 2020 07/05]; Available from: https://www.adl.org/blog/reports-of-anti-asianassaults-harassment-and-hate-crimes-rise-ascoronavirus-spreads.

35. Rogin, A. \& Nawaz, A. 'We have been through this before.' Why anti-Asian hate crimes are rising amid coronavirus. 2020 2020-06-25 [cited 2020 07/04]; Available from: https://www.pbs.org/newshour/nation/we-havebeen-through-this-before-why-anti-asian-hate-crimesare-rising-amid-coronavirus.

36. House, R.J., Hanges, P.J., Javidan, M., Dorfman, P.W., \& Gupta, V. (2004). Culture, leadership, and organizations: The GLOBE study of 62 societies. Sage publications.

37. Lee, S.M., Peterson, S.J. (2000). Culture, entrepreneurial orientation, and global competitiveness. J World Bus, 35(4):401-16.

38. Pham, N., Li, Y., Schapsis, C., Hossain, T., Pham, H., Fischer, D. (forthcoming). Intrinsic cultural factors that helped Vietnam to overcome the COVID-19 pandemic compared with other countries. AsiaPacific Journal of Health Management.

39. Hofstede, G., \& Hofstede, G.J. (2005). Organisationer och kulturer.

40. Lin, W. T., \& Shao, B. B. M. (2000). The relationship between user participation and system success: A simultaneous contingency approach. Information \& Management, 37(6), 283-295.

41. Lin, W. T., \& Shi, J. (2020). Chief executive officer compensation, firm performance, and strategic coopetition: A seemingly unrelated regression approach. Managerial \& Decision Economics, 41(1), 130-144. 
TABLE A1: DEMOGRAPHICS OF THE INTERVIEW PARTICIPANTS

\begin{tabular}{|c|c|c|}
\hline PARTICIPANT & AGE & GENDER \\
\hline Yen Trinh & 26 & Female \\
\hline Nhi & 23 & Female \\
\hline Anh & 21 & Male \\
\hline Nguyen & 24 & Male \\
\hline Khanh & 24 & Male \\
\hline Quynh & 19 & Female \\
\hline Trang & 29 & Female \\
\hline Thang & 33 & Male \\
\hline Minh & 23 & Male \\
\hline Kim & 22 & Female \\
\hline Vy & 24 & Female \\
\hline Minh Hieu & 27 & Female \\
\hline Lan & 25 & Female \\
\hline My & 21 & Female \\
\hline Trung & 22 & Male \\
\hline Lam & 21 & Male \\
\hline Nam & 22 & Male \\
\hline Thanh & 25 & Female \\
\hline Phuong & 25 & Female \\
\hline Thu & 23 & Female \\
\hline
\end{tabular}

